\title{
Buffer Zone Community Forestry in Nepal: Examining Tenure and Management Outcomes
}

\author{
Sudeep Jana Thing ${ }^{1}$ and Buddi S Poudel ${ }^{2}$ \\ ${ }^{1}$ Department of Planning and Geography, Curtin University, Western Australia, ${ }^{2}$ Department of Forest \\ Research and Survey, Ministry of Forest and Soil Conservation \\ Corresponding author: janasudeep@gmail.com
}

\begin{abstract}
This paper examines the transfer of management rights over forests and natural resources and exercise of such rights by various sections of local communities in Protected Area (PA) buffer zones in Nepal. The study is based on an extensive review of government policy documents, available published and grey materials. The paper has also been drawn from the long experiences of the authors working in PAs and buffer zones in various parts of the country. We found that Buffer Zone Community Forests (BZCFs) have so far made significant contribution to biodiversity conservation, local livelihoods and institutional building in buffer zones. However, we also found a range of critical challenges in realising clear, comprehensive and secure rights by the local communities. Effective functioning of buffer zone community forestry is undermined by ever-increasing demand of forest products, lack of needed management autonomy and support from the PA management authorities, absence of clear policy guideline, increasing human-wildlife conflict and persistence of social exclusion of women, poor and marginalised. We argue that a better understanding and attention to address tenure related challenges in BZCFs would aid both conservation and local livelihoods and thereby enhance socio-ecological resilience of buffer zone communities.
\end{abstract}

Keywords: Buffer zone, buffer zone community forest, conservation, livelihoods, tenure

\section{INTRODUCTION}

Global shifts in the approaches to development since 1980s that emphasised concerns of peoples' participation, local empowerment and decentralisation have shaped the thinking and practices of Protected Areas (PAs) (Campbell 2005). The thrust towards local participation has led to a conceptual convergence of conservation and development discourses, facilitated the rise of the paradigm of community conservation (Fisher et al. 2005) and the emergence of initiatives known as Integrated Conservation and Development Programs/Projects (ICDPs) (Brandon and Wells 1992; Wells and Brandon 1992). This shift was very much articulated in the World Conservation Strategy, 1980 following the failures of conventional fence and fine approach.
A distinctive feature of ICDPs addressing both conservation and development concerns is the practice of Buffer Zone $(B Z)^{1}$ management (Sayer 1991). Nepal has also witnessed a shift from conventional, strict conservation to participatory conservation (Wells and Sharma 1998). The concept of $\mathrm{BZ}$ was introduced to reconcile both conservation goal and locally sustainable development needs (Heinen and Mehta 2000; Bajimaya 2003; Budhathoki 2004), which is an important policy innovation and tenure reform in PAs to institutionalise participatory conservation.

1 Buffer Zone is an area in and around PA that can be considered as impact zone, and includes the area directly affected by (i) the prohibited use of forest products of PAs, (ii) the grazing in the PAs, and (iii) the wildlife (e.g., crop damage) of PAs regularly or occasionally. 
The move towards ICDPs, however, generated backlashes globally. While the conservationists were concerned about the conflation of conservation and development, scholars raised concerns about the reversal of community based conservation initiatives (e.g., Adams and Hutton 2007) and a resurgence of the protectionist paradigm (Wilshusen et al. 2002). Practices of community based conservation or ICDP has been argued to be as authoritarian and ineffective as fortress conservation and can sometimes generate negative consequences (Temudo 2012) and fell short of fulfilling its social and environmental objectives (NaughtonTreves et al. 2005). Despite the successes of BZ program, there are several criticisms such as: it still operates in a conventional style and lack local people's participation (Wells and Brandon 1992); it changes the landuse practices, which at times have negative consequences on the local poor (Neumann 1997; Lynagh and Urich 2002); it is fraught with social inequalities (Paudel 2006) or failed to transform the lives of natural resource dependent indigenous peoples (Thing 2014). It also accentuated a sense of tenure insecurity on the part of the local people due to the extension of state authority over the settlements and surrounding land beyond the PAs (Neumann 1997).

Successful experiences of community forestry in Nepal have also translated in the $\mathrm{BZ}$ since the adoption of participatory conservation in the early 1990s. Buffer zone community forest (BZCF) has been an integral component of PA and BZ management. BZCF is a form of decentralised and community based forest management in the BZ with several key objectives (e.g., Bajimaya 2003; DNPWC
2013; Bhusal 2014; DNPWC 2015) such as (i) to address the local communities' needs and demands of forest resources (e.g., firewood and fodder) and generate income from tourism, (ii) to reduce the dependency of local population on the PA resources and thereby mitigate the pressures on PA forest resources and eventually improve biodiversity and wildlife habitat restoration, (iii) to conserve forest as extended habitat for the wildlife, (iv) to motivate local communities for PA management, biodiversity conservation, forest management, and (v) to eventually resolve park-people conflicts over resource use (Straede and Treue 2006) and thereby harmonise 'park-people' relations.

The seminal work of Springate-Baginski and Blaikie (2007) on political ecology of forestry reforms and participatory forest management in Nepal mentions community forestry being promoted in BZ only in passing. Paudel et al. (2013) acknowledges unique tenure, institutional arrangement and different bundle of rights in BZ community forestry but respective issues are not unpacked. Jhaveri and Adhikari (2016) caution against the discretionary control of the PA Warden in the BZCFs in the absence of clear regulatory guidelines. In examining the property rights in BZ forests, Harini and Gokhale (2008) raised concerns over lack of tenure security for the local users, and hinted predominance of state control over forest management plans. With exceptions of these works and others (e.g. Jones 2007; Jana 2009; Sherpa 2014) examination of the tenure issues pertaining to BZCFs are largely inadequate.

This paper attempts to contribute to the significant gap in the conservation and forestry literatures in general and 
community tenures debates in forestry and PAs in particular by inquiring rights and tenure in community forestry within the pretext of BZ. We outline the current status, policy and legal context of BZCFs; we then offer our assessment of rights and tenure security, multiple outcomes, and critical issues and challenges associated with BZCFs. The paper is largely based on extensive review of secondary literatures. However, it is also informed by our years of engagements in PAs and BZs in different parts of Nepal and policy debates either as researchers or government official. We argue in the pretext of both successes and challenges of BZCFs, adequate understanding and attention to the tenure related challenges and issues of BZCFs as critical socio-ecological systems, which would give support to conservation as well as socio-economic outcomes and thereby enhance resilience of $\mathrm{BZ}$ communities and forests.

\section{EVOLUTION OF BUFFER ZONE COMMUNITY FORESTS}

Participatory BZ programme is the flagship programme of Nepalese conservation sector that demonstrate significant forest and PA tenure reforms. BZ program was initiated during 1990 s to strengthen the interrelationship between PA and local community living in and around it. This policy reform stems on the history and crucial lessons from the persistence of 'Park-People' conflicts emanating from the centralised government management of PAs, local exclusion in the conservation programme, local restriction on natural resources access, and human-wildlife conflicts (e.g., Stevens 1997; Jana 2007; Paudel et al. 2007; Jana 2008). BZ management program aims to conserve, protect and promote biodiversity in PAs (including BZ) through local peoples' participation and sharing of resources and revenues with the local population (Bajimaya 2003; Budhathoki 2004).

National Parks and Wildlife Conservation (NPWC) Act of 1973 is a key legislation in conservation of biodiversity and the management of Nepal's PAs, including the management of BZs. The fourth amendment of the NPWC Act in 1992 incorporated provisions for BZ. Subsequently the BZ Management Regulation 1996 and Guidelines 1999 were approved to implement BZ programme and to facilitate participation of local population in the conservation, management and governance of BZ. These are chief legislations that govern the co-management of $\mathrm{BZ}$ between PA administration and local peoples' institutions (see Figure 1).

These laws make provisions for 30 to 50 per cent of PA revenues to be retained for conservation and community development activities in the $\mathrm{BZ}$. The revenue is disbursed through a BZ Management Committee/Council (BZMC) and several BZ user group/committee (BZUG/ BZUC) to the local communities. BZ programme is primarily focused on improving the socio-economic wellbeing of the local communities and reducing their dependency on PA resources. The forest in the BZ can be sustainably managed under community forest, religious forest and private forest (HMGN 1996). The BZ Management Regulation, 1996 is the key legal instrument to promote community forests in BZ. 


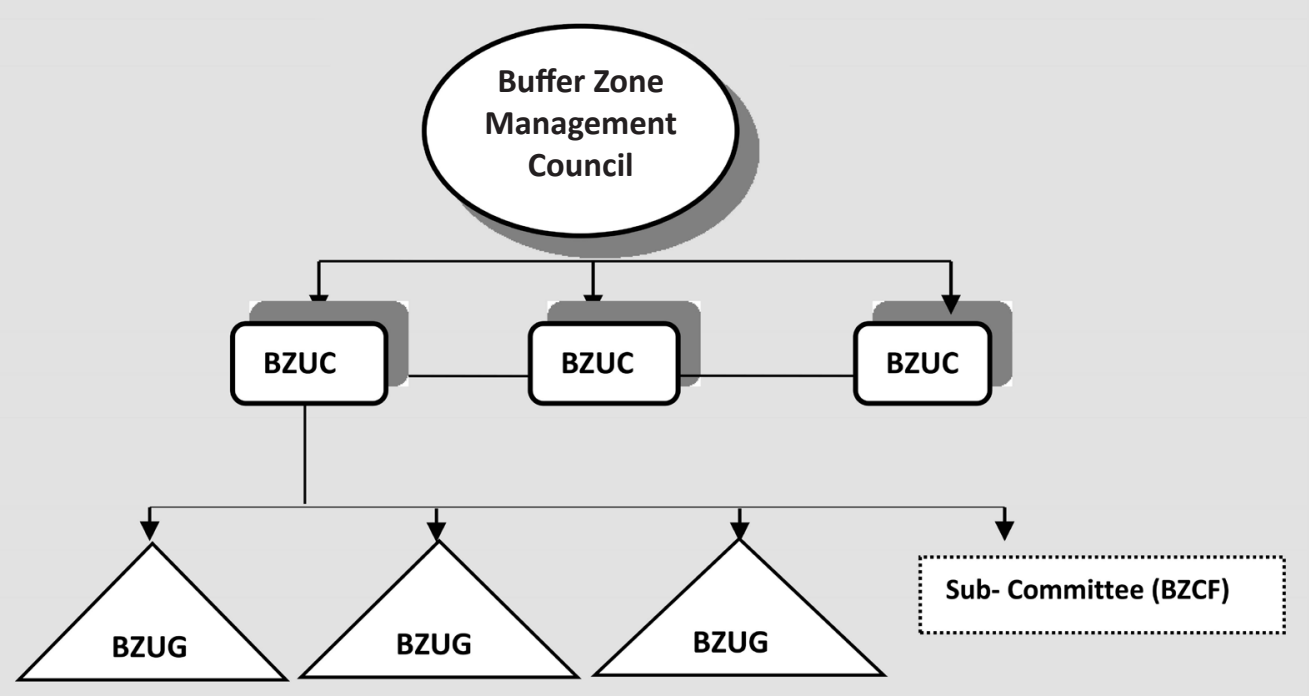

Figure 1: Three-tier Structure of Community based People's Institution in the Buffer Zone Management.

Nepal Biodiversity Strategy and Action Plan briefly mentions BZCFs for improvement in management of $\mathrm{PA}$ and species, and in with respect to "reviewing and strengthening governance and management of BZs" that entails "addressing the issue related to management of community ..... forests located inside BZ, and improving financial management" (MoFSC 2014: 87). Despite the significance of BZCFs to biodiversity conservation, it does not unpack or discuss the issues of BZCFs and related strategies adequately. With respect to communication, education and outreach strategy to increase awareness about biodiversity and ecosystem services it also states "Designing and implementation of programmes to raise awareness and build capacity of local community based forest user groups in the corridors and BZ user groups for conservation-friendly and climate responsive management of the forests" (MoFSC 2014: 100).
The concept, institutionalisation and practice of BZCFs are embedded in the participatory conservation policy and tenure reform in relation to management of BZs. The BZ Management Regulation (1996) provides some legal space for BZCFs. According to the Regulation, the PA warden is responsible for the conservation of wildlife, natural environment and resources, biodiversity and forests in the BZ. The Regulation defines BZCFs as one of the three categories of forest in PA BZs (i.e., religious forest, private forest and community forest) that is ".... handed over to the users' committee under Rule 21". As per the respective rule, BZCF could be handed over to the local residents of the BZ as:

If the users' committee is interested to take any forest area as a BZCF in the area prescribed as the buffer community forest for the management of buffer zone under the Rule-4 [...unit division of BZ....] shall 
apply to the warden in a format mentioned in the Appendix-3 [....application to register a BZCF...] (HMGN 1996).

The BZUC identifies the forest that can be handed over as community, religious and private forests within the BZ in its work plan. The work plan also includes: the management and conservation of forests, wildlife and environment; methods of forest products collection; silvicultural systems and reforestation; and methods of distribution, management and sale of forest resources. Forest management and use is therefore stated as one of the key functions, duties and powers of the BZUC prescribed by the law, "to prescribe the type, quantity, area to be used, method, time and fees for forest resources necessary for the daily use of local people annually" (HMGN 1996).

According to Rule 11 of the BZ legislation, BZUC can form a sub-committee to carry out its duties. Forest in the BZ is handed over by the PA administration to the BZUC not directly to the BZCF User Groups. BZCF is integrated to the structure of $\mathrm{BZ}$ management institutions. The legal status of the BZCF is that of a sub-committee of the BZUC (see Figure 1) rather than an autonomous community institution.

The BZUC lodges application for the legal hand over and registration of BZCFs along with its work plan to the PA administration. The warden provides technical assistance to prepare the five years work plan and approves the extent and quantity of forest resources. Upon approval, the PA warden issues the certificate of registration as BZCF. While handing over, a tripartite agreement between Buffer Zone Community Forest
Users' Group (BZCFUG), BZUC and PA warden is made (Paudel et al. 2007) to articulate commitment of these actors in following rules and work plan.

Despite the legal status of BZCFUGs to that of a sub-committee of BZUC, they are also governed by their constitution and five year operational plans approved by the PA warden (or renewed in case of termination of operational plans if their existence and operation as community forests under Forest Act and Rules predate the declaration of $\mathrm{BZ}$ ). Experiences on the ground also suggest a mismatch and inconsistencies between the legal rules of BZ and actual practices and functioning of BZCFs. In practice, BZCFUGs function in a manner similar to Community Forest User Groups (CFUGs) outside BZ with their constitution, operational/work plans, governing body under executive committee and general assembly. However, these aspects are not clearer in the BZ rules. This can be attributed to the lack of separate guidelines on the regulation and management of BZCF.

While the history of interactions between local communities and forest resources, and practices of resource use is older than the creation of PAs and BZs, the state authority of PA management and its conservation partners have actively been promoting BZCFs through creating enabling policy environment for conservation and sustainable use of forests. In fact, the management plans of PAs stress handing over of community forests to local population in the BZ as one of the achievements of PAs. Gradually, local communities and their institutions in the BZs have been increasingly claiming their stakes in BZCFs. Now, BZCF is conceived as one of the key forest 
management strategy DNPWC 2015) as well as a strategy of zonation referred as 'Sustainable Use Zone' (DNPWC 2016), entailing "forested area in BZ, which is managed by community for dual purpose of meeting the need of forest products for the households and providing refuge for dispersing population of wildlife" (DNPWC 2013: 67).

The handing over of forests by the state authorities, PA management to local communities in the BZ legally began as early as late 1990s in both lowland and High Mountain PAs. As of 2016, there were 546 BZCFs managing 130,558 sq. Km, where 94,626 households are accessing the forests (Table 1 ). There are many community forests formed under the forestry legal regimes (under the jurisdiction of the Department of Forest) that predate the official declaration and establishment of several BZs in the 1990s, which eventually came within the legal jurisdiction of PAs. A trend of handing over of BZCFs, beneficiaries and forest area under community tenure and control in the BZs throughout the country have been increasing.

Table 1: Buffer Zone Community Forest in Protected Areas of Nepal as of 2016

\begin{tabular}{clcrr}
\hline SN & Protected Area & $\begin{array}{c}\text { Number of } \\
\text { BZCF }\end{array}$ & $\begin{array}{c}\text { Area of } \\
\text { BZCF (ha) }\end{array}$ & $\begin{array}{r}\text { Number of } \\
\text { Households }\end{array}$ \\
\hline 1 & Chitwan NP & 53 & $28,292.00$ & 25,543 \\
2 & Bardia NP & 85 & $13,568.98$ & 24,254 \\
& Shuklaphanta Wildlife Reserve & 35 & $1,743.50$ & 8,855 \\
3 & (WLR) & 41 & $10,384.14$ & 12,182 \\
4 & Parsa WLR & 24 & $2,617.09$ & 1,541 \\
5 & Shey Phoksundo NP & 9 & $22,067.60$ & 804 \\
6 & Sagarmatha NP & 89 & $40,850.15$ & 6,574 \\
7 & Makalu Barun NP & 78 & $5,825.98$ & 7,822 \\
8 & Langtang NP & 11 & 126.54 & 1,926 \\
9 & Koshi Tappu WLR & 12 & $1,612.12$ & 1,160 \\
10 & Rara NP & 13 & $1,141.76$ & 1,422 \\
11 & Khaptad NP & 71 & $2,328.33$ & 2,543 \\
12 & Banke NP & 25 & & - \\
13 & Shivapuri-Nagarjun NP* & 546 & 130558.19 & 94626 \\
Total & & & & \\
\hline
\end{tabular}

Source: Department of National Parks and Wildlife Conservation. *BZCF ranges from 0.77 to 63.9 hectare (Bowers et al. 2017). 


\section{BUNDLE OF RIGHTS AND COMMUNITY TENURE IN BZCF}

The BZCFUGs enjoy rights to use and manage forests in the $\mathrm{BZ}$ based on the work plans and constitution approved by the PA administration. They operate within the legal regime of $\mathrm{PA}$ and $\mathrm{BZ}$ management. As BZCFs are managed for conserving biodiversity and its sustainable use while meeting the subsistence need of forest products for local communities in the BZ, BZCFUGs are constrained in allowing tree-felling permits. Also, commercial uses and supplying or sale of the forest products (e.g., timber and firewood) from BZCFs to areas outside the $\mathrm{BZ}$ is prohibited. However, BZUC can distribute excessive forest products to neighbouring and/or other BZUCs within the BZ. In case of other forest products (e.g., medicinal plants, and Khair - Acacia catechu) can be sold outside BZ with permission from the PA administration.

Although day-to-day affairs and decisions concerning forest use and conservation are carried out collectively by BZCFUGs, forest management and governance in the BZ also fall within the authority of the PA warden. Therefore, PA warden has a considerable influence and authority over plans and functioning of BZCFUGs. Infact it is the collective responsibility of BZUC, BZCFUGs and PA administration. Hence, BZCFs can be considered as a form of co-governance and management. The warden can dissolve the BZUC and BZCFUGs, If they act against approved work plan, or fails to accomplish the duties and responsibilities, or does prohibited activities in the BZ. They do not have clear duration of tenure and in practice largely operated under the surveillance of the PA warden (Jhaveri and Adkhikari 2016). However there is not clear provisions for BZCFs.

The current rules do not have clear provisions for financial accounting system of BZCFUG. However in practice, BZCFUGs, following the general practice of CFUGs outside BZ, deposit earnings generated from the sale of forest resources (e.g., fallen wood, firewood, and grass) as their core funds. Such funds need to be officially, annually audited.

While permitting tree harvesting and timber transportation, there are different practices constraining the rights of BZCFUGs. For instance, Sagarmatha NP administration withdraws all the timber seals of the BZCFUGs and uses only one seal. Its staff rather than the BZCFUG members handle the seal. This has been argued as power recentralization by the PA authority (Sherpa 2014). Despite enjoying multiple rights to use, conserve and manage resources, BZCFUGs have limited autonomy and are constrained in tenure security over forest and its resources (Table 2). Also, there are no collective networks of BZCFs to partner or negotiate rights with the PA administration. Hence, security of forest tenure in BZCFs within the participatory regime of $\mathrm{PA}$ and $\mathrm{BZ}$ management could be contested in the absence of clearer rules and concrete policy framework. 
Table 2: Tenure Rights of BZCFUGs

\begin{tabular}{|c|c|}
\hline Types of rights & Status of rights \\
\hline \multirow[t]{2}{*}{$\begin{array}{l}\text { Rights to access and } \\
\text { use }\end{array}$} & $\begin{array}{l}\text { Members can access forest products sustainably as per the work plan } \\
\text { approved by PA warden; by paying nominal fees prescribed. }\end{array}$ \\
\hline & Issuing tree harvesting permits for sale outside of the $\mathrm{BZ}$ is constrained. \\
\hline Right to manage & $\begin{array}{l}\text { BZCFUG manage and conserve the forest as per the work plan. The } \\
\text { PA management also has authority to manage forest in the BZ. }\end{array}$ \\
\hline \multirow[t]{2}{*}{ Rights to govern } & $\begin{array}{l}\text { BZCFUG and PA authority collectively make the decisions on forest } \\
\text { use and conservation. }\end{array}$ \\
\hline & $\begin{array}{l}\text { A tripartite agreement between the PA administration, BZUC and } \\
\text { BZCFUG exist to govern BZCF management. }\end{array}$ \\
\hline $\begin{array}{l}\text { Rights to sell forest } \\
\text { products }\end{array}$ & $\begin{array}{l}\text { There is restriction on sale of forest products (e.g., timber and fire- } \\
\text { wood) outside the BZ. However, there is no restriction to sell forest } \\
\text { products (e.g., medicinal plants, Khair). }\end{array}$ \\
\hline $\begin{array}{l}\text { Responsibility to } \\
\text { conserve }\end{array}$ & $\begin{array}{l}\text { There exist collective responsibility of BZUC, BZCFUG and PA } \\
\text { administration to conserve BZCFs. }\end{array}$ \\
\hline Right to dissolution & $\begin{array}{l}\text { Despite the clear legal provisions, PA warden has authority to cancel } \\
\text { the registration of the BZCF in case of violation of work plan. }\end{array}$ \\
\hline Right to exclude & $\begin{array}{l}\text { BZCFUG in practice decide its members, local residents of BZ, who } \\
\text { could use and access the resources. }\end{array}$ \\
\hline $\begin{array}{l}\text { Legal status/basis / } \\
\text { registration }\end{array}$ & $\begin{array}{l}\text { BZCFUGs are registered as a sub-committee of BZUC, which do not } \\
\text { have separate, clear legal status. However, in practice they are regis- } \\
\text { tered at the PA administration, showing a weak legal status. }\end{array}$ \\
\hline $\begin{array}{l}\text { Right to manage } \\
\text { finances/earnings }\end{array}$ & $\begin{array}{l}\text { There are no clear rules to guide BZCFUGs manage financial resourc- } \\
\text { es. However, in practice, BZCFUGs create funds and operate bank } \\
\text { accounts, which are audited officially by the PA administration. }\end{array}$ \\
\hline $\begin{array}{l}\text { Networking to ad- } \\
\text { vocate and advance } \\
\text { rights }\end{array}$ & $\begin{array}{l}\text { There is weak (i) networking among BZCFUGs, (ii) relations with a } \\
\text { respective BZUC, and (iii) networking among BZUCs in the BZ man- } \\
\text { agement council. }\end{array}$ \\
\hline
\end{tabular}

\section{OUTCOMES}

Conservation outcomes: Despite the absence of comprehensive studies on the conservation outcomes of BZCFs in Nepal, available evidences underscore and suggest contribution of BZCFs in forest and biodiversity conservation. For instance, local communities are conserving biodiversity in BZCFs (e.g., Jana 2009; Jana and Paudel 2010); significant forest recovery (e.g., Stapp et al. 2015) and improved forest condition .... (Pokharel 2009) is occurred in the BZCFs of Chitwan NP; there is improved ecological condition and forest cover outside PA in general (Paudel et al. 2007). Likewise, there is increased species richness of vegetation, density of forests, regeneration of plants, and wildlife in BZCFs (Timalsina 2007). The pristine natural forests that were severely degraded before the formation 
of BZ in the Sagarmatha NP have now witnessed the revival of secondary growth forests and improvement of habitats, forest biomass and greenery through voluntary conservation of local communities over the last one and a half decades (Sherpa 2013). Improved forest in the mid hills BZCFs of Langtang NP were also found in such a way that significantly supported the local livelihoods (Sherchan et al. 2016).

BZCFs in the lowlands provide an extended habitat for mega fauna, including some of the endangered species such as tiger and rhino. Sharma et al. (2011: 61) affirm "During pre-community management period, Baghmara area was encroached and degraded due to different activities and the presence of animals was rare. However, after the establishment of Buffer Zone Community Forest it became the resting place for frequently visiting large mammals". Wild ungulates, including different species of deer were found in Bagmara (Sharma et al. 2013). Likewise, floristic diversity was found higher in BZCF than in community forest in Chitwan (Dhakal et al. 2011). Bird species diversity has also been recorded in BZFCs (Wagle 2009). Sullivan et al. (2017) noted the critical role of BFCFs to manage the threats of invasive plants, particularly Mikania.

Socio-economic significance/outcomes: BZCFs are critical for rural and agrarian livelihoods in the BZ as local access to natural resources in the PA is limited and constrained. Local communities collect fallen wood, fuelwood, grass, thatch, fodder, wild vegetables, fruits, wetland resources from the BZCFs for subsistence. Fuelwood derived from both BZCFs and nearby community forests is the main source of energy for many local communities (Thapa 2015). BZCFs support the rural livelihoods, particularly the poor and landless (e.g., Gaire 2006; Paudel 2014; Bhandari and Jianhua 2017) with notable economic values of the products harvested (e.g., Straede and Treue 2006). In fact, poor households were found to have stake and are more supportive of forest conservation (e.g., Stapp et al. 2016).

In addition to the access to natural capital, BZCF has also enhanced diverse livelihood assets and capitals (Gaire 2006; Timalsina 2007). For instance, it has provided rural communities to initiate micro-enterprises through harvesting of non-timber forest products such as Fragrant Wintergreen (scented oil) in case of Syaubari BZCF in the Langtang NP (SHL/LNPBZSP 2010). PA management plans recognise the prospects of tourism in BZCFs and generation of livelihoods opportunities for local communities (DNPWC 2013, 2015). The case of Bagmara BZCF in Chitwan NP has been exemplary in forest conservation both active plantation and regeneration, sustainable resource use for local livelihoods and deriving economic benefits though community based ecotourism (Rijal 1997). However, by taking a case of Chitwan NP, Straede and Treue (2006) demonstrated that significant gaps persists in local people's resource need and current rights irrespective of BZCFs, even though the role of national forest to substitute products from PAs is significant and substitution effect of BZCF is relatively small.

\section{KEY CHALLENGES}

BZCFs confront numerous critical challenges. First, the demographic pressure, ever increasing population especially in the lowland BZ, and subsequent increasing demand for timber and fuelwood puts 
pressure on the forest resources. This raises a pressing question of the ability of BZCFs to meet the local demands for forest resources. This is coupled with an irony of tourism based economy and opportunities. In the context of highland BZ, where the tourism-based economy is booming, and associated local tourism infrastructure development projects heighten the demand for timber and changes timber market (Sherpa 2013). While the problems of forest encroachment and informal settlements are much more complex and multifactorial, often resulting in conflicts between forest conservation and land rights, particularly in the lowlands, it has been noted as a serious threat, "Forest encroachments, illegal squatters and settlers pose serious problem in $\mathrm{BZ}$ community forest management" (DNPWC 2015).

Second, the autonomy of BZCF as an institution has been questioned and debated (e.g., Jana 2009; Biswokarma et al. 2011; Sherpa 2013). The legal and institutional provisions of BZCF are not strong enough for local institutions (e.g., BZCFUG) to function as autonomous and perpetual local institutions for managing community forests (Paudel et al. 2007). As noted earlier in the absence of specific policy or regulatory guidelines and government directives on the management and governance of BZCF, there are mismatches between the current practice of $\mathrm{BZCF}$ and $\mathrm{PA}$, and $\mathrm{BZ}$ rules of the state, and more importantly further reinforces discretionary power of the PA warden over the BZCFs (Jhaveri and Adhikari 2016).

Third, despite the promotion of BZCFs by the PA authorities, representatives and leaders of $\mathrm{BZ}$ have conveyed, during policy deliberations, concerns about the pending or slow handover process of BZCFs (Biswokarma et al. 2011). Thereby “.... slow response to pending applications of community forestry has discouraged many local communities" (Paudel et al. 2007).

Fourth, occurrence of human-wildlife conflict in and around PAs in Nepal is well researched (e.g., Acharya et al. 2016) and many of them have indicated that the increased forest regeneration and extended habitat in BZCFs and community forests beyond BZ, wildlife related incidents and human-wildlife conflicts have raised (Paudel et al. 2007; Bowers et al. 2017). In some cases, there have been increased wildlife sightings and therefore increased vulnerabilities to human-wildlife conflicts (Gaire 2006). As noted by Paudel et al. (2007: 50), this has been a 'paradox' of BZCF.

Fifth, given the unequal power relations and hierarchical structures in the society, issues of inequity and social exclusion of women, poor, landless, so called lower caste - dalits and indigenous peoples appear to be critical in BZCFs. Representation of these marginalised groups in governance institutions are often poor (Paudel et al. 2007) therfore resulting in inequities in distribution of benefits. Researchers have noted stressed problems of equity in BZCFs (e.g., Harini, and Gokhale 2008; Jana 2009; Jhaveri and Adhikari 2016). Jones (2007) argued that despite seemingly fair management practices, there are variations in the institutions of BZCFs that "reproduce favourable resource access conditions for elites and benefit distribution does seem to be skewed in favour of the wealthy and higher castes". For instance, despite the representation of women, no Musahars (an ethnic group traditionally involved in fishing) were 
involved in the executive committee in Baghmara BZCF and therefore the affluent members often made decisions reflecting, and leading into, inequitable distribution of benefits for women, poor and Musahar (Prasain 2006). In other cases, BZCFs have also been found to interfere with the customary rights of traditional and indigenous fishing communities in the rivers (Prasain 2006; Jana 2009; Thing 2014).

\section{CONCLUSION}

It is evident that BZCFs are critical socioecological systems, which are vital for conservation of forest and biodiversity in PAs and BZs, as well as significant to local livelihoods given the interactions of rural and agrarian people with the natural environment and resources. BZCFs are critical institutions of local communities, which are complementing the goals and efforts of PA and BZ management. Strengths and successes of BZCFs are attributed to the agencies of local communities, their conservation stewardship, stake in forest resources and incentives in forest conservation. It is important to note that this has been aided by forest tenure and conservation reforms in the state policy and legislations as well as ongoing support of PA authorities and its conservation partners.

BZCFs however are also fraught with numerous challenges mediated by both endogenous and exogenous factors that need adequate attention. Local communities are constrained to sell timber and firewood outside the BZ given the conservation and ecological sensitivity of PAs, which is still a contentious issue between community tenure over forest and goal of conservation. Despite the enabling policy environment, we contend that BZCFUGs are not fully autonomous and powerful given its legal status, have less secure forest tenure and operate under the considerable influence of PA warden. While some legal space exists for BZCFs, an absence of clearer and specific legal provisions and guidance for BZCFUGs, adds complexities to the management, governance and long-term forest tenure in BZCFs.

BZCFs continue to benefit local livelihoods and conservation, and can be reconceptualised as a powerful right-based model of conservation that reconcile rights and responsibilities of local communities and conservation actors (Jana 2009). As also claimed by Sherpa (2013), it has a potential to offer opportunities to indigenous peoples in regaining forest governance, management and use rights and opening avenues for local communities in claiming stake on forest resources and conservation. We envisage the sustenance of BZCFs is going to be shaped by future enabling policies on tenure security, mutual partnerships as well as power relationships and negotiations between local population and the state PA authorities.

\section{ACKNOWLEDGEMENT}

We would like to thank Ganesh Pant for data and inputs during the initial outline of the paper, and reviewers and editors for their constructive comments.

\section{REFERENCES}

Acharya, K.P., Paudel, P.K., Neupane, P.R. and Kohl, M. 2016. Human-Wildlife Conflicts in Nepal: Patterns of Human Fatalities and Injuries Caused by Large Mammals. PLOS ONE, 11(9). e0161717. doi:10.1371/journal. pone. 0161717 .

Adams, W.M. and Hutton, J. 2007. People, Parks and Poverty: Political Ecology and Biodiversity 
Conservation. Conservation and Society, 5(2): 147-183.

Bajimaya, S. 2003. Nepal's Experience in Participatory Biodiversity with Emphasis on Buffer Zone Initiatives. Policy Matters, 12: 276282.

Bhandari, D. and Jianhua, Z. 2017. Household Dependency on Buffer Zone Community Forest and its Implication for Management of Chitwan National Park, Nepal. International Journal of Sciences, 6(3): 68-80.

Bhusal, N.P. 2014. Buffer Zone Management System in Protected Areas of Nepal. The Third Pole: Journal of Geography, 11-12: 34-44

Biswakarma, D., Gurung, N. and Paudel, N. 2011. Revisiting Protected Area Buffer Zones: Exploring Legal and Institutional Reforms in Buffer Zone Management. Synthesis Report. ForestAction Nepal, Lalitpur, Nepal.

Bowers, J., Dickerson, A. and Yuan, Q. 2017. Buffer Zone Planning in Nepal's ShivapuriNagarjun National Park: Inclusive Program Development for More Resilient Park-People Relations and the Protection of Ecological Services in the Kathmandu. Master Thesis, University of Michigan, USA.

Brandon, K. E. and Wells, M. 1992. Planning for People and Parks: Design Dilemmas. World Development, 20(4): 557-570.

Budhathoki, P. 2004. Linking Communities with Conservation in Developing Countries: Buffer Zone Management Initiatives in Nepal. Oryx, 38(3): 334-341.

Campbell, B. 2005. Changing Protection Policies and Ethnographies of Environmental Engagement. Conservation and Society, 3(2): 280-322.

Dhakal, R. R., Kafle, G. and Yadava, J. N. 2011. Comparative Assessment of Floristic Diversity in a Buffer Zone Community Forest and a Community Forest of Barandabhar Corridor, Chitwan, Nepal. Journal of Horticulture and Forestry, 3(8): 244-250.

DNPWC. 2013. Chitwan National Park and its Buffer Zone: Management Plan (2013-2017). Department of National Parks and Wildlife Conservation, Ministry of Forests and Soil Conservation, Kathmandu, Nepal.
DNPWC. 2015. Bardia National Park and Buffer Zone Management Plan (2016-2020). Department of National Parks and Wildlife Conservation, Ministry of Forests and Soil Conservation, Kathmandu, Nepal.

DNPWC. 2016. Sagarmatha National Park and its Buffer Zone: Management Plan (2016-2020). Department of National Parks and Wildlife Conservation, Ministry of Forests and Soil Conservation, Kathmandu, Nepal.

Fisher, R. J., Maginnis, S., Jackson, W. J., Barrow, E., and Jeanrenaud, S. 2005. Poverty and Conservation: Landscapes, People and Power. Gland, Switzerland: IUCN.

Gaire, D. 2006. An Assessment of Community-based Biodiversity Conservation and Rural Livelihood Improvements in the Buffer Zone of Bardia National Park. A Report Submitted to The Rufford Maurice Laing Foundation, Rufford Small Grant for Nature Conservation (RSG), UK.

Harini, N. and Gokhale. Y. 2008. Management Regimes, Property Rights, and Forest Biodiversity in Nepal and India. Environmental Management, 41(5):719-733. doi: 10.1007/ s00267-008-9073-y.

Heinen, J.T. and Mehta, J. N. 2000. Emerging Issues in Legal and Procedural Aspects of Buffer Zone Management with Case Studies from Nepal. The Journal of Environment Development, 9(1): 45-67.

HMGN. 1996. Buffer Zone Management Regulation 1996. His Majesty's Government of Nepal, Kathmandu, Nepal.

Jana, S. 2007. Voices from the Margins: Human Rights Crisis in Protected Areas of Nepal. Policy Matters, 15: 87-99.

Jana, S. 2008. Protecting People in Protected Areas: Recapitulating Rights Campaign in Lowland Protected Areas of Nepal. Community Development Organization, Kathmandu, Nepal.

Jana, S. 2009. Rights Based Approaches to Natural Resource Management in Buffer Zone Community Forests: Learning from the Grassroots. In: J. Campese, T. Sunderland, T. Greiber and G. Oviedo (Eds.), Rights-based Approaches: Exploring Issues and Opportunities for Conservation (pp. 185-202). CIFOR, Bogor, Indonesia. 
Jana, S. and Paudel, N.S. 2010. Rediscovering Indigenous Peoples and Community Conserved Areas in Nepal. ForestAction Nepal, Lalitpur, Nepal.

Jhaveri, N.J. and Adhikari, J. 2016. Nepal Land and Natural Resource Tenure Assessment for Proposed Emission Reductions Program in the Terai Arc Landscape. USAID Tenure and Global Climate Change Program, Washington DC, USA.

Jones, S. 2007. Tigers, Trees and Tharu: An Analysis of Community Forestry in the Buffer Zone of the Royal Chitwan National Park, Nepal. Geoforum, 38(3): 558-575.

Lynagh, F.M. and Urich, P.B. 2002. A Critical Review of Buffer Zone Theory and Practice: A Philippines Case study. Society and Natural Resources, 15:129-145.

MoFSC. 2014. Nepal National Biodiversity Strategy and Action Plan (2014 - 2020). Ministry of Forests and Soil Conservation, Kathmandu, Nepal.

Naughton-Treves, L., Holland, M. B. and Brandon, K. 2005. The Role of Protected Areas in Conserving Biodiversity and Sustaining Local Livelihoods. Annual Review of Environmental Resources, 30: 219-252.

Neumann, R.P. 1997. Primitive Ideas: Protected Area Buffer Zones and the Politics of Land in Africa. Development and Change, 28(3): 559582.

Paudel, M.K. 2014. Buffer Zone Community Forest and their Contribution: A Case Study of Chitrasen Buffer Zone Community Forest User Groups. Master's Dissertation, Birendra Multiple Campus, Tribhuwan University.

Paudel, N.S. 2006. Protected Area and Reproduction of Social Inequality. Policy Matters, 14: 155-168.

Paudel, N.S., Budhathoki, P. and Sharma, U.R. 2007. Buffer Zones: New Frontiers for Participatory Conservation? Journal of Forest and Livelibood, 6(2): 44-53.

Paudel, N.S., Khatri, D.B., Khanal, D.R. and Karki, R. 2013. The Context of REDD+ in Nepal: Drivers, Agents, and Institutions. CIFOR, Bogor, Indonesia.
Paudel, N.S., Jana, S. and Rai, J.K. 2012. Contested Law: Slow Response to Demands for Reformulating Protected Area Legal Framework in Nepal. Journal of Forest and Livelihood, 10(1): 88-100.

Pokharel, R. 2009. People, Pressure and Conservation Issues of Bandevi Barandavar Buffer Zone Community Forest, Chitwan National Park, Nepal. Master Dissertation, University of Idaho, USA.

Prasain, R.B. 2006. Will Poor People and Women Benefit Too? In: D. Murdiyarso and M. Skutsch (Eds.), Community Forest Management as a Carbon Mitigation Option: Case Studies (pp 35-42). CIFOR, Bogor, Indonesia.

Rijal, A. 1997. The Baghmara Community Forest: An Example of Linkages between Community Forestry and Ecotourism. In: J. Bornemeier, M. Victor and P.B. Durst (Eds.), Ecotourism for Forest Conservation and Community Development (pp 144-50), Proceedings of an International Seminar, 28-31 January 1997. RECOFTC and FAO, Bagkok, Thailand.

Sayer, J.A. 1991. Rainforest Buffer Zones: Guidelines for Protected Area Managers. IUCN, Gland, Switzerland.

Sharma, B.K., Chalise, M.K. and Solanki, G. S. 2011. Large Wildlife Population in Bagmara Buffer Zone Community Forest, Nepal. Ecoprint: An International Journal of Ecology, 18: 55-62. doi:10.3126/eco.v18i0.9411.

Sharma, B.K., Solanki, G.S. and Chalise, M.K. 2013. Wild Ungulate Population in Baghmara Buffer Zone Community Forest, Nepal. Journal of Natural History Museum, 27: 66-71.

Sherchan, R., Rijal, K. and Bajracharya, S.B. 2016. Assessing Contribution of Local Community in Biodiversity Conservation at Laharepauwa of Rasuwa, Nepal. Journal of Ecology and the Natural Environment, 8(6): 90-98.

Sherpa, M.N. 2013. Conservation Governance and Management of Sagarmatha (Mt. Everest) National Park, Buffer Zone, and Buffer Zone Community Forest User Groups in Pharak, Nepal. PhD Dissertation, University of Massachussets, Amherst, USA.

SHL/LNPBZSP. 2010. Biodiversity Conservation and Sustainable Livelihoods: Success Stories. Sacred Himalayan Landscape (SHL)/Langtang 
National Park and Buffer Zone Support Project(LNPBZSP). WWF Nepal, Kathmandu, Nepal.

Springate-Baginski, O. and Blaikie. P. (Eds.). 2007. Forest, People and Power: Political Ecology of Reform in South Asia. London: Earthscan.

Stapp, J.R., Lilieholm, R.J., Leahy, J. and Upadhaya, S. 2016. Linking Attitudes, Policy, and Forest Cover Change in Buffer Zone Communities of Chitwan National Park, Nepal. Environmental Management, 57(6): 1292-1303.

Stapp, J.R., Lilieholm, R.J., Upadhaya, S. and Johnson, T. 2015. Evaluating the Impacts of Forest Management Policies and CommunityLevel Institutions in the Buffer Zone of Chitwan National Park, Nepal. Journal of Sustainable Forestry, 34(5): 445-464.

Stevens, S. 1997. Consultation, Co-Management, and Conflict in Sagarmatha (Mount Everest) National Park, Nepal. In: S. Stevens (Ed.), Conservation through Cultural Survival: Indigenous Peoples and Protected Areas. (pp 6397). Washington, DC: Island Press.

Stræede S. and Treue T. 2006. Beyond Buffer Zone Protection: A Comparative Study of Park and Buffer Zone Products' Importance to Villagers Living Inside Royal Chitwan National Park and to Villagers Living in its Buffer Zone. Journal of Environmental Management, 78: 251-267.

Sullivan, A., York, A.M., White, D.D., Hall, S. J. and Yabiku, S.T. 2017. De Jure Versus De Facto Institutions: Trust, Information, and Collective Efforts to Manage the Invasive Mile-a-minute Weed (Mikania micrantha). International Journal of the Commons, 11(1): 171-199. DOI:http://doi.org/10.18352/ijc.676

Temudo, M. P. 2012. "The White Men Bought the Forests": Conservation and Contestation in
Guinea-Bissau, Western Africa. Conservation and Society, 10(4), 354-366.

Thapa, K. 2015. Buffer Zone Community Perception, Attitude and Belief towards the Newly Established Protected Areas: A Case Study from Banke National Park. Final Report Submitted to Rufford Small Grant Foundation, UK.

Thing, S.J. 2014. The Polemics and Discourse of Conservation in Nepal: A Case Study of Sonaha Indigenous Minorities and Bardia National Park. $\mathrm{PhD}$ Dissertation, Curtin University, Perth, Western Australia.

Timilsina, L.B. 2007. Contribution of Buffer Zone Management on Livelihood Support. A Case Study from Chitwan National Park, Nepal. A Master's Dissertation, University of Klagenfurt, Austria.

Wagle, R. 2009. Effects of Management and Disturbance Gradients on a Bird Fauna in Chitwan National Park and its Buffer Zone. Master's Thesis, Swedish Biodiversity Centre, Uppsala, Sweden. http://stud.epsilon.slu. se/659/1/wagle_r_091125.pdf

Wells, M.P. and Brandon, K.E. 1992. People and Parks: Linking Protected Areas with Local Communities. Washington DC: The World Bank.

Wells, M.P. and Sharma, U.R. 1998. SocioEconomic and Political Aspects of Biodiversity Conservation in Nepal. International Journal of Social Economics, 25(2/3/4): 226-243.

Wilshusen, P.R., Brechin, S.R., Fortwangler, C.L. and West, P.C. 2002. Reinventing a Square Wheel: Critique of a Resurgent "Protection Paradigm" in International Biodiversity Conservation. Society and Natural Resources, 15(1): 17-40. 